\title{
IDENTIFIKASI DAN KARAKTERISTIK HABITAT JENIS LUMUT KERAK DI TAMAN WISATA ALAM SICIKEH-CIKEH KABUPATEN DAIRI SUMATERA UTARA
}

\author{
Melfa Aisyah Hutasuhut ${ }^{*}$, Husnarika Febriani ${ }^{1}$, Sutra Devi ${ }^{1}$ \\ ${ }^{1}$ Universitas Islam Negeri Sumatera Utara \\ *melfa aisyah@uinsu.ac.id
}

\begin{abstract}
ABSTRAK
Lumut kerak adalah hasil simbiosis dari fungi dan alga. Penelitian ini dilakukan untuk mengetahui jenis-jenis lichen di Taman Wisata Alam Sicikeh-cikeh Kabupaten Dairi Sumatera Utara. Metode yang digunakan merupakan metode survey eksploratif yaitu menjelajahi sepanjang jalur lokasi penelitian. Pada penelitian ini ditemukan 19 jenis yaitu lichen dari 7 famili. 8 jenis dari famili yaitu Parmeliaceae (Parmotrema arnoldii (Du Rietz) Hale, Usnea dasypoga (Acharius.) Nyl., Usnea barbata (L.) Weber ex F.H.Wigg., Cetrelia olivetorum (S.) Sticto., Hypogymnia physodes (L.) Nyl., Bulbothrix tabacina (Mont.) Hale, Parmotrema perlatum (Huds.) M. Choisy and Parmelia sulcata (Taylor.), 4 jenis dari famili Cladoniaceae yaitu Pseudevernia cladonia (Tuck.) W. L. Culb., Cladonia rangiferina (L.) Weber ex F.H.Wigg., Cladonia cristatella (Tuck.), 3 jenis dari famili Lobariaceae yaitu Sticta sylvatica (Hudson). Ach., Pseudocyphellaria anthraspis (Ach.) H. Magn. dan Sticta crocodia (Ach). Masing-masing 1 jenis dari famili Physciaceae (Heterodermia leucomalos (L.) Kalb.), Pertusariaceae (Ochrolichia subviridi (Hoeg) Erichsen.), Trentepohliaceae (Trentopohlia flava (Kutzing) De Toni.), and Pyrenulaceae (Pyrenula sulcata Eschw.). Karakteristik habitat Lumut kerak yang di temukan memiliki karakteristik habitat dengan menempel di pohon, hidup di serasah dan tanah dengan tipe talus Crustose 2 jenis dengan ciri talus berbentuk mirip kulit yang menempel ketat pada substratnya, tipe talus Foliose 8 jenis dengan karakteristik tumbuh seperti semak dan tipe talus Fruticose 9 jenis dengan ciri berwarna hijau dengan struktur permukaan halus.
\end{abstract}

Kata Kunci: Identifikasi, Karakteristik Habitat, Lumut Kerak, TWA Sicikeh Cikeh

\begin{abstract}
Lichen are a symbiotic result of fungi and algae. This research purpose to determine the types of lichens in the Wisata Nature Park Sicikeh-cikeh, Parbuluan District, Dairi Regency, North Sumatera. The Method was used in this research a survey exploration of method that is by exploring along the path of the research location. In this study found 19 species of lichens from 7 families. 8 types of family Parmeliaceae (Parmotrema arnoldii (Du Rietz) Hale, Usnea dasypoga (Acharius.) Nyl., Usnea barbata (L.) Weber ex F.H.Wigg., Cetrelia olivetorum (S.) Sticto., Hypogymnia physodes (L.) Nyl., Bulbothrix tabacina (Mont.) Hale, Parmotrema perlatum (Huds.) M. Choisy and Parmelia sulcata (Taylor.), 4 types of family Cladoniaceae (Pseudevernia cladonia (Tuck.) W. L. Culb., Cladonia rangiferina (L.) Weber ex F.H.Wigg., Cladonia cristatella (Tuck.) and Cladonia squamosa (S.) Hoffm. Var.), 3 types of family Lobariaceae (Sticta sylvatica (Hudson). Ach., Pseudocyphellaria anthraspis (Ach.) H. Magn. and Sticta crocodia (Ach).), and only 1 type from the family Physciaceae, (Heterodermia leucomalos (L.) Kalb.), Pertusariaceae (Ochrolichia subviridi (Hoeg) Erichsen.), Trentepohliaceae (Trentopohlia flava (Kutzing) De Toni.), and Pyrenulaceae (Pyrenula sulcata Eschw.). The habitat characteristic of Lichen have a by efifit to trees, living in litter and soil with 2 species of Crustose thallus type with skin-like thallus characteristics that are tightly attached to the substrate, 8 species of Foliose thallus type with bush-like growth characteristics and 9 spesies of Fruticuse thallus type with a characteristic green color with a smooth surface strcture.
\end{abstract}

Keywords: Inventory, Habitat Characteristics, Lichen, TWA Sicikeh Cikeh

\section{PENDAHULUAN}

Hutan ialah habitat makhluk hidup yang terdiri dari pohon, vegetasi alam dan hewan lainnya yang saling berasosiasi di lingkungan dan membentuk komunitas hidup. Hutan sebagai komunitas biologi yang terjadi interaksi 
kompleks antara makhluk hidup (biotik) dengan lingkungan (abiotik) (Wanggai, 2009).

Lumut kerak atau disebut juga lichen merupakan hasil simbiosis dari dua jenis organisme makhluk hidup yang berbeda, yaitu fungi dan alga. Kebanyakan fungi yang ikut menyusun tubuh Lichen adalah golongan Ascomycetes dan alga yang ikut berperan menyusun tubuh. Lichen adalah golongan ganggang biru (Chanophyceae) dan ganggang hijau (Chlorophyceae) (Tjitrosoepomo, 2005). Alga dalam lichen berperan sebagai penyedia karbohidrat, sedangkan fungi berfungi menyerap air dan mineral, sekaligus berperan sebagai penyedia struktur dan massa serta perlindungan (Mulyadi, 2007).

Lichen memiliki talus dengan empat tipe yang berbeda yaitu foliose, crustose, squamulose, dan fruticose. Lichen umumnya hidup bersifat epifit di pepohonan, permukaan batu, tanah lembab dan gunung yang tinggi. Lichen dapat berperan sebagai indikator lingkungan dan juga terlibat dalam proses pelapukan biologis (Marianingsih, 2017).

Bersumber data Herbarium Bogoriensis dalam Muslim \& Hasairin (2018) mengatakan bahwa jumlah jenis lichen yang ada di Indonesia tersebar mencapai 40.000 jenis sehingga perlu dilakukan eksplorasi lebih dalam untuk mengetahui jenis-jenis lichen tersebut. Peluang yang terbuka ini, belum banyak dimanfaatkan oleh periset di Indonesia. Hal ini dapat dilihat dari buku-buku biologi yang hanya membahas tentang beberapa jenis lichen yang baru diketahui spesiesnya, dari perbandingan jumlah spesies lichen di Indonesia hingga 40.000 spesies (Hasairin, 2016).

TWA Sicikeh-cikeh merupakan salah satu dari enam hutan lindung yang terdapat di Sumatera Utara yang memiliki lichen. TWA ini merupakan hutan lindung dibawah naungan Balai Besar Konservasi Sumber Daya Alam (BBKSDA) yang terletak di Kecamatan Parbuluan Kabupaten Dairi Provinsi Sumatera Utara. TWA Danau Sicikeh- cikeh, terutama jalur perjalanan Danau I, Danau II dan Danau III memiliki pancaran sinar matahari yang cukup. Selain itu, tempatnya yang asri dan minim polusi membuat lichen tumbuh melimpah dan berkembang dengan baik di daerah tersebut. Akan tetapi, hingga saat ini belum pernah dilaporkan data mengenai lichen yang hidup di TWA Danau Sicikeh-cikeh.

Data penelitian yang pernah dilakukan penting untuk dijadikan informasi bagi semua kalangan yang akan memanfaatkan lichen dan dapat dijadikan sumber literatur keanekaragaman lichen di suatu daerah. Lichen dapat digunakan sebagai obat-obatan (Septiana, 2011), pemantauan polusi, pewarna dan bahan pembuatan parfum.

Berdasarkan penjelasan dari kalimat diatas, Tujuan dari penelitian ini bertujuan untuk mengindentifikasi jenis lichen, mengetahui karakteristik habitat lichen, dan mendeskripsikan jenis lichen di TWA Sicikehcikeh Desa Lae Hole Kecamatan Parbuluan Kabupaten Dairi Sumatera Utara.

\section{METODE}

Penelitian ini berlangsung mulai bulan Oktober hingga Desember 2019 di TWA Sicikehcikeh. Pengambilan sampel lichen dilakukan di tiga jalur perjalanan yaitu Danau I, Danau II dan Danau III di TWA Danau Sicikeh-cikeh menggunakan metode survey observatif dengan cara menjelajahi lokasi penelitian untuk memperoleh sampel yang dibutuhkan.

Alat dan Bahan yang digunakan dalam penelitian ini yaitu: GPS (Global Position System) berfungsi mengenali titik koordinat posisi penelitian, kamera berfungsi mendokumentasikan kegiatan hasil penelitian, lux meter berfungsi mengukur intensitas cahaya, hygrometer berfungsi mengukur satuan suhu dan kelembapan udara, Soil tester berfungsi mengukur $\mathrm{pH}$ dan kelembapan tanah, Lup berfungsi membantu proses dokumentasi, penggaris befungsi mengukur panjang dan lebar spesimen, Cutter berfungsi membantu dalam pengambilan spesimen, alat tulis berfungsi sebagai perlengkapan pencatatan selama penelitian, amplop berfungsi menyimpan sampel penelitian, botol handspray berfungsi sebagai 
Melfa Aisyah Hutasuhut et al., Identifikasi dan Karakteristik Habitat Jenis Lumut Kerak

Di Taman Wisata Alam Sicikeh-Cikeh Kabupaten Dairi Sumatera utara

Jurnal Biolokus: Jurnal Penelitian Pendidikan Biologi Dan Biologi Vol.4 (1)

tempat alkohol 70\%, alkohol 70\% berfungsi untuk pengawetan sampel penelitian dan kertas label berfungsi sebagai label sampel di masingmasing amplop.

Prosedur kerja yang dilakukan dalam penelitian dibagi dalam lima tahap yaitu: survey awal penelitian, pengamatan, pengambilan sampel, penentuan jenis dan analisis data. Survei awal dilakukan pada bulan Mei 2019 untuk melihat kondisi lokasi penelitian dan untuk mengetahui bagaimana informasi lichen $\mathrm{di}$ Taman Wisata Alam Danau Sicikeh-cikeh.

Pengamatan dan pengambilan sampel lichen dilaksanakan di jalur perjalanan Danau I, Danau II dan Danau III di TWA Danau Sicikeh-cikeh. Setiap sampel yang ditemukan didokumentasikan lalu diambil data berupa: jenis-jenis lichen yang ditemukan, letak ditemukan lichen, karakteristik habitat lichen dan data faktor lingkungan lichen seperti suhu, kelembaban, $\mathrm{pH}$ dan lain-lain. Setiap sampel yang mewakili jenis lichen diawetkan terlebih dahulu untuk diindentifikasi lebih lanjut. Pengawetan pada lichen dengan menyemprotkan alkohol 70\% lalu sampel lichen dimasukan ke dalam amplop yang diberi label untuk nantinya diidentifikasi di Laboratorium Biologi, Fakultas Sains dan Teknologi Universitas Islam Sumatera Utara.

Hasil data penelitian yang diperoleh dari lapangan kemudian dianalisis kualitatif secara deskriptif dengan mencantumkan nama ilmiah lichen dan disajikan dalam bentuk gambar ataupun tabel serta dilakukan deskripsi jenisjenis lichen dan karakteristik habitat lichen.

\section{HASIL DAN PEMBAHASAN \\ Jenis-Jenis Lichen (Lumut Kerak) di TWA Danau Sicikeh-cikeh}

Hasil penelitian yang dilakukan di tiga jalur perjalanan yaitu Danau I, Danau II dan Danau III di Taman Wisata Alam Danau Sicikeh-cikeh Desa Lae Hole Kecamatan Parbuluan Kabupaten Dairi Sumatera Utara, telah ditemukan jenis-jenis lichen sebanyak 19 spesies yang meliputi 7 famili yang dapat dilihat pada Tabel 1.

Tabel 1. Jenis-jenis lichen (lumut kerak) yang ditemukan di Taman Wisata Alam Danau Sicikeh-cikeh

\begin{tabular}{|c|c|c|c|c|}
\hline \multirow{2}{*}{ Famili } & \multirow{2}{*}{ Spesies } & \multicolumn{3}{|c|}{ Lokasi Penelitian } \\
\hline & & Danau I & Danau II & Danau III \\
\hline \multirow{8}{*}{ Parmeliaceae } & Parmotrema arnoldii (Du Rietz) Hale & $\sqrt{ }$ & $\sqrt{ }$ & $\sqrt{ }$ \\
\hline & Usnea dasypoga (Acharius.) Nyl. & $\sqrt{ }$ & $\sqrt{ }$ & $\sqrt{ }$ \\
\hline & Usnea barbata (L.) Weber ex F.H.Wigg & $\sqrt{ }$ & & $\sqrt{ }$ \\
\hline & Cetrelia olivetorum (S.) Sticto. & $\sqrt{ }$ & & \\
\hline & Hypogymnia physodes (L.) Nyl. & $\sqrt{ }$ & & $\sqrt{ }$ \\
\hline & Bulbothrix tabacina (Mont.) Hale & $\sqrt{ }$ & $\sqrt{ }$ & $\sqrt{ }$ \\
\hline & Parmotrema perlatum (Huds.) M. Choisy & $\sqrt{ }$ & $\sqrt{ }$ & $\sqrt{ }$ \\
\hline & Parmelia sulcata (Taylor.) & & & $\sqrt{ }$ \\
\hline \multirow{4}{*}{ Cladoniaceae } & Pseudevernia cladonia (Tuck.) W. L. Culb. & $\sqrt{ }$ & & \\
\hline & Cladonia rangiferina (L.) Weber ex F.H.Wigg. & $\sqrt{ }$ & & $\sqrt{ }$ \\
\hline & Cladonia cristatella (Tuck.) & $\sqrt{ }$ & & $\sqrt{ }$ \\
\hline & Cladonia squamosa (S.) Hoffm. Var. & & $\sqrt{ }$ & \\
\hline \multirow{3}{*}{ Lobariaceae } & Sticta sylvatica (Hudson). Ach. & $\sqrt{ }$ & & $\sqrt{ }$ \\
\hline & Pseudocyphellaria anthraspis (Ach.) H. Magn. & $\sqrt{ }$ & & $\sqrt{ }$ \\
\hline & Sticta crocodia Ach. & $\sqrt{ }$ & & $\sqrt{ }$ \\
\hline Physciaceae & Heterodermia leucomelos (L.) Kalb & $\sqrt{ }$ & & \\
\hline Pertusariaceae & Ochrolechia subviridis (Hoeg) Erichsen & $\sqrt{ }$ & $\sqrt{ }$ & $\sqrt{ }$ \\
\hline Trentepohliaceae & Trentepohlia flava (Kutzing) De Toni & $\sqrt{ }$ & $\sqrt{ }$ & $\sqrt{ }$ \\
\hline Pyrenulaceae & Pyrenula cerina Eschw. & $\sqrt{ }$ & & $\sqrt{ }$ \\
\hline
\end{tabular}


Jurnal Biolokus: Jurnal Penelitian Pendidikan Biologi Dan Biologi Vol.4 (1)

Dari Tabel 1 hasil penelitian mengenai lichen di Taman Wisata Alam Danau Sicikehcikeh Desa Lae Hole Kecamatan Parbuluan Kabupaten Dairi Sumatera Utara, diperoleh sampel lichen sebanyak 19 spesies dari 7 famili yang diketahui. Penyebaran famili terdiri dari Parmeliaceae 8 spesies, famili Cladoniaceae memiliki 4 spesies, famili Lobariaceae memiliki 3 spesies, dan masing-masing dari famili Physciaceae, famili Pertusariaceae, famili Trentepohliaceae dan famili Pyrenulaceae memiliki 1 spesies.

Lichen yang paling banyak dijumpai di Taman Wisata Alam Danau Sicikeh-cikeh dan banyak mendominasi adalah famili Parmeliaceae yang terdiri dari 8 spesies. Salah satu faktor yang menyebabkan famili Parmeliaceae banyak ditemukan pada penelitan ini karena famili Parmeliaceae dapat hidup dipermukaan substrat dengan struktur morfologi kasar, pecah-pecah ataupun dengan permukaan halus dan mempunyai toleransi cukup baik pada lingkungan dengan kualitas udara yang kurang menguntungkan. Perihal ini didukung oleh pendapat Asih $d k k$, (2013), yang mengatakan bahwa famili Parmeliaceae merupakan famili dari divisi Lecanoramycetes yang memiliki jumlah spesies terbesar dan mampu tumbuh dalam lingkungan tercemar.

Jenis lichen yang paling sedikit diperoleh pada adalah dari famili Physciaceae, Pertusariaceae, Trentepohliaceae dan Pyrenulaceae yang masing-masing berjumlah 1 spesies di lokasi penelitian. Salah satu faktor yang menyebabkan sedikitnya jumlah famili tersebut didapat karena ada beberapa famili tertentu dari lichen memiliki daya toleransi yang rendah terhadap kualitas udara (polutan). Menurut Fithri (2017), bahwa salah satu jenis Pyxine cocoes dari famili Physciaceae tidak tergolong sensitif terhadap polusi. Lichen tidak akan dapat tumbuh secara maksimal apabila memiliki sifat sensitivitas yang tidak baik terhadap polusi lingkungan, sehingga hal ini dapat mempengaruhi keanekaragaman spesies Lichen di lingkungan tersebut.
Lichen yang ditemukan di jalur perjalanan Danau I sebanyak 17 spesies, di jalur perjalanan Danau II sebanyak 7 spesies dan jalur perjalanan Danau III ditemukan 15 spesies. Area Danau I dan area Danau III ditemukan lebih banyak jenis lichen dibandingkan area Danau II, hal ini dapat dipengaruhi oleh struktur area lokasi lichen tumbuh, sehingga adanya perbedaan distribusi lichen pada masingmasing area, disebabkan faktor kelembapan udara (\%) dan intensitas cahaya (cd) pada habitat tertentu. Pada Danau I didapatkan kelembapan udara 84\% dan intensitas cahaya 1125 cd, Danau II didapatkan kelembapan udara 88\% dan intensitas cahaya $1124 \mathrm{~cd}$, dan Danau III didapatkan kelembapan udara $80 \%$ dan intensitas cahaya 1126 cd. Kelembapan udara merupakan faktor yang mempengaruhi penyerapan lichen terhadap nutrien dan air, apabila kelembapan udara di lingkungan diatas 85\% dan intensitas cahaya dibawah $1125 \mathrm{~cd}$, maka proses fotosintesis tidak berjalan efektif, sehingga dapat menghambat metabolisme tumbuhnya lichen pada area tersebut. Hal ini didukung oleh Murningsih \& Husna (2016), lichen mampu hidup dan mengalami fotosintesis pada lingkungan yang lembab sebesar 85\%, apabila kondisi lingkungan $>85 \%$ efektifitas lichen dalam berfotosintesis akan berkurang sebesar 35-40\%.

\section{Faktor Fisik Lingkungan}

Jenis lichen yang tumbuh di Taman Wisata Alam Danau Sicikeh-cikeh tidak lepas dari faktor fisik yang dapat mendukung tumbuh dan berkembangnya lichen di daerah tersebut. Faktor fisik lingkungan yang diukur yaitu suhu, kelembaban, $\mathrm{pH}$ tanah dan intesitas cahaya yang terdapat dalam Tabel 2.

Tabel 2. Faktor fisik lingkungan lichen di Taman Wisata Alam Danau Sicikeh-cikeh

\begin{tabular}{lccc}
\hline \multicolumn{1}{c}{ Faktor Fisik } & \multicolumn{3}{c}{ Danau } \\
\cline { 2 - 4 } \multicolumn{1}{c}{ Lingkungan } & I & II & III \\
\hline Suhu udara $\left({ }^{\circ} \mathrm{C}\right)$ & 21 & 20 & 24 \\
\hline Kelembaban udara $(\%)$ & 84 & 88 & 80 \\
\hline Suhu tanah $\left({ }^{\circ} \mathrm{C}\right)$ & 18 & 18 & 21 \\
\hline Kelembaban tanah \%) & 80 & 70 & 70 \\
\hline Int. cahaya $(\mathrm{cd})$ & 1125 & 1124 & 1126 \\
\hline
\end{tabular}


Melfa Aisyah Hutasuhut et al., Identifikasi dan Karakteristik Habitat Jenis Lumut Kerak

Di Taman Wisata Alam Sicikeh-Cikeh Kabupaten Dairi Sumatera utara

Jurnal Biolokus: Jurnal Penelitian Pendidikan Biologi Dan Biologi Vol.4 (1)

Berdasarkan Tabel 2 dari hasil pengukuran faktor fisik lingkungan di Taman Wisata Alam Danau Sicikeh-cikeh, diperoleh data faktor fisik yang mendukung tumbuh dan berkembangnya lichen. Faktor fisik lingkungan sangat mempengaruhi keberadaan lichens di habitatnya. Menurut Murningsih dan Husna (2016), bahwa lichen mampu tumbuh pada suhu tinggi dan rendah disebabkan lichen dapat beradaptasi pada kisaran suhu dengan toleransi yang luas. Apabila lichen tumbuh pada lingkungan yang tidak menguntungkan, lichen mampu beradaptasi hingga kondisi lingkungan normal kembali. Suhu lingkungan diatas $45^{\circ} \mathrm{C}$ mampu merusak klorofil lichen sehingga dibutuhkan suhu dibawah $40^{\circ} \mathrm{C}$ untuk pertumbuhan maksimal lichen dan intensitas cahaya sebesar $1025 \mathrm{~cd}$ adalah intensitas terendah lichen agar dapat melakukan fotosintesis dengan baik (Fithri, 2017).
Suhu udara di wilayah penelitian berkisar $20^{\circ} \mathrm{C}-24^{\circ} \mathrm{C}$ dan kelembaban udara berkisar dari $80-88 \%$, suhu tanah berkisar dari $18^{\circ} \mathrm{C}-21^{\circ} \mathrm{C}$, kelembaban tanah berkisar dari 70-80\%, pH tanah berkisar dari 5-7 dan intensitas cahaya pada saat penelitian 1124-1126 cd. Berdasarkan kondisi lingkungan penelitian, lichen mampu hidup di TWA Danau Sicikehcikeh karena adanya dukungan dari faktor fisik lingkungan yang dapat mempengaruhi keberadaan lichen dan juga mempengaruhi penyebaran lichen di lingkungan penelitian.

\section{Karakteristik Habitat Lichen}

Pengamatan karakteristik habitat lichen di TWA Danau Sicikeh cikeh dilakukan dengan mengamati substrat tempat menempelnya lichen, ketinggian dan titik koordinat ditemukannya lichen yang disajikan dalam Tabel 3.

Tabel 3. Karakteristik habitat lichen di Taman Wisata Alam Danau Sicikeh-cikeh

\begin{tabular}{|c|c|c|c|}
\hline Spesies & Substrat & $\begin{array}{l}\text { Ketinggian } \\
\text { (mdpl) }\end{array}$ & Titik Koordinat \\
\hline Pseudocyphellaria anthraspis (Ach.) H. Magn. & Serasah & 1403 & N: $02^{\circ} 39^{\prime} 07.0^{\prime \prime}$ E: $098^{\circ} 23^{\prime} 13.1^{\prime \prime}$ \\
\hline Cladonia rangiferina (L.) Weber ex F.H.Wigg. & Tanah & 1411 & $\mathrm{~N}: 02^{\circ} 39^{\prime} 09.0^{\prime \prime} \mathrm{E}: 098^{\circ} 23^{\prime} 14.1^{\prime \prime}$ \\
\hline Cladonia cristatella(Tuck.) & Tanah & 1408 & N: $02^{\circ} 39^{\prime} 08.8^{\prime \prime}$ E: $098^{\circ} 23^{\prime} 14.2^{\prime \prime}$ \\
\hline Pseudevernia cladonia (Tuck.) W. L. Culb & Pohon & 1397 & N: 02³9'21.8” E: $098^{\circ} 23^{\prime} 24.0^{\prime \prime}$ \\
\hline Sticta sylvatica (Hudson) Ach & Pohon & 1408 & N: $02^{\circ} 39^{\prime} 20.8^{\prime \prime}$ E: $098^{\circ} 23^{\prime} 23.6^{\prime \prime}$ \\
\hline Heterodermia leucomelos (L.) Kalb & Pohon & 1407 & N: $02^{\circ} 39^{\prime} 08.6^{\prime \prime}$ E: $098^{\circ} 23^{\prime} 14.1^{\prime \prime}$ \\
\hline Ochrolechia subviridis (Hoeg) Erichsen & Pohon & 1407 & N: $02^{\circ} 39^{\prime} 08.6^{\prime \prime}$ E: $098^{\circ} 23^{\prime} 14.1^{\prime \prime}$ \\
\hline Usnea dasypoga (Acharius.) Nyl. & Pohon & 1407 & N: $02^{\circ} 39^{\prime} 08.6^{\prime \prime}$ E: $098^{\circ} 23^{\prime} 14.1^{\prime \prime}$ \\
\hline Trentepohlia flava (Kutzing) De Toni & Pohon & 1407 & N: 02³9'08.6" E: 098²3'14.1" \\
\hline Parmotrema arnoldii (Du Rietz) Hale & Pohon & 1396 & N: 02³9'21.8” E: $098^{\circ} 23^{\prime} 24.2^{\prime \prime}$ \\
\hline Usnea barbarata (L.) Weber ex F.H. Wigg. & Pohon & 1403 & N: $02^{\circ} 39^{\prime} 07.0^{\prime \prime} \mathrm{E}: 098^{\circ} 23^{\prime} 13.1^{\prime \prime}$ \\
\hline Cladonia squamosa (S.) Hoffm. Var. & Pohon & 1411 & N: 02³9'06.7" E: $098^{\circ} 22^{\prime} 51.3^{\prime \prime}$ \\
\hline Cetrelia olivetorum (S.) Stricto. & Pohon & 1407 & N: $02^{\circ} 39^{\prime} 08.9^{\prime \prime}$ E: $098^{\circ} 23^{\prime} 14.3^{\prime \prime}$ \\
\hline Hypogymnia physodes (L.) Nyl. & Pohon & 1386 & N: $02^{\circ} 39^{\prime} 10.0^{\prime \prime}$ E: $098^{\circ} 22^{\prime} 40.3^{\prime \prime}$ \\
\hline Bulbothrix tabacina (Mont.) Hale & Pohon & 1384 & N: 02³9'15.7" E: 098²2’31.7" \\
\hline Parmotrema perlatum (Huds.) M. Choisy & Pohon & 1386 & N: $02^{\circ} 39^{\prime} 16.5^{\prime \prime}$ E: $098^{\circ} 22^{\prime} 31.5^{\prime \prime}$ \\
\hline Parmelia sulcata (Taylor.) & Pohon & 1387 & N: $02^{\circ} 39^{\prime} 16.7^{\prime \prime}$ E: $098^{\circ} 22^{\prime} 33.3^{\prime \prime}$ \\
\hline Pyrenula cerina Eschw. & Pohon & 1384 & N: 02³9'15.7" E: 098²2’31.7" \\
\hline Sticta crocodia Ach. & Pohon & 1384 & N: 02³9'15.7" E: 098²2’31.7" \\
\hline
\end{tabular}


Jurnal Biolokus: Jurnal Penelitian Pendidikan Biologi Dan Biologi Vol.4 (1)

Berdasarkan Tabel 3 dari pengamatan karakteristik habitat lichen di TWA Danau Sicikeh-cikeh, diperoleh hasil pengamatan bahwa lichen dapat menempel pada serasah, tanah dan pohon. Lichen yang menjadikan serasah sebagai substrat habitatnya ditemukan 1 spesies yaitu Pseudocyphellaria anthraspis (Ach.) H. Magn. Lichen yang menempel pada tanah sebagai substratnya ditemukan sebanyak 2 spesies yaitu Cladonia rangiferina (L.) Weber ex F.H. Wigg dan Cladonia cristatella (Tuck.) dan 16 spesies lainnya ditemukan epifit di pohon.

Secara umum lichen dapat hidup dimanapun dan tidak memiliki persyaratan khusus yang dapat mempengaruhi perkembangannya (Roziaty, 2016a). Spesies lichen membutuhkan kondisi lingkungan yang cukup air dan terdapat banyak unsur zat hara dan didukung dengan kandungan oksigen yang tinggi sehingga pada penelitian ini banyak ditemukan spesies lichen pada substrat pohon dipermukaan kayu. Murningsih (2016) mengatakan, secara umum banyak jenis lichen menjadikan kulit pohon sebagai substrat tempat tumbuhnya, sehingga secara langsung kondisi morfologi kulit pohon dapat mempengaruhi bentuk talus yang tumbuh dan jenis lichen yang berkembang akan berbeda bentuk talusnya sesuai dengan morfologi substrat tempat melekatnya. Lichen yang menempel di atas tanah dan serasah berfungsi dalam proses pembentukan tanah dan termasuk dalam kelompok tumbuhan perintis.

Talus pada tumbuhan tak berpembuluh merupakan organ vegetatif (Mulyani, 2021). Talus memiliki karakteristik yang berbeda sesuai substrat tumbuhnya yaitu susunan talus yang menempel rapat atau jarang pada substratnya, dapat tegak lurus atau terangkat dari substrat dan terlihat menggantung atau menjuntai pada substrat (Laksono, 2016).

\section{Tipe Talus pada setiap spesies lichen}

Lichen memiliki talus dengan empat tipe yang berbeda, yaitu crustose, fruticose, foliose dan squamolose.

\section{Crustose}

Crustose merupakan jenis lichen dengan morfologi datar, berukuran kecil dan tipis dan menempel pada permukaan batuan, permukaan tanah dan bagian atas kulit pohon. Lichen crustose ada dua yaitu endolitik dan endoploidik. Crustose endolitik adalah jenis lichen yang tumbuh dari bagian dalam batuan, sedangkan crustose endoploidik adalah jenis lichen yang dapat tumbuh dari jaringan tumbuhan (Chandra, 2015). Contoh: Lepraria incana dan Lecanora thysanophara.

\section{Fruticose}

Fruticose memiliki tipe talus bercabang tidak teratur yang sangat kompleks, berbentuk silinder dan bagian dasar talus menempel kuat pada substrat dengan cakram bertingkat. Lichen tipe fruticose tumbuh pada daun, permukaan pohon dan permukaan batuan. Contoh: Bryoria fuscescens.

\section{Foliose}

Lichen foliose umumnya melekat lebih longgar pada substrat tempat menempelnya dan memiliki struktur menyerupai daun. Talus foliose umumnya lebar dan menyerupai daun yang berkerut memutar dengan banyak lekukan. Contoh: Parmelia plumbea dan Parmelia caperata.

\section{Squamulose}

Jenis Lichen ini memiliki struktur lobus menyerupai sisik, dengan ukuran lobus yang kecil dan saling tumpang tindih. Contoh jenis Lichen squamulose adalah Cladonia sp. dan Psora pseudorusselli.

Pengamatan deskripsi jenis lichen di TWA Danau Sicikeh-cikeh dilakukan dengan mengamati tipe talus pada setiap spesies. Berdasarkan Tabel 4 dari pengamatan deskripsi jenis lichen di TWA Danau Sicikeh-cikeh, diperoleh lichen dengan tipe talus Crustose sebanyak 2 spesies dengan ciri talus berbentuk mirip kulit yang menempel ketat pada substratnya (Utari \& Roziaty, 2017). Tipe talus Foliose sebanyak 8 spesies dengan karakteristik tumbuh seperti semak dan Fruticose sebanyak 9 spesies dengan ciri berwarna hijau dengan struktur permukaan halus (Utari \& Roziaty, 2017). 
Melfa Aisyah Hutasuhut et al., Identifikasi dan Karakteristik Habitat Jenis Lumut Kerak

Di Taman Wisata Alam Sicikeh-Cikeh Kabupaten Dairi Sumatera utara

Jurnal Biolokus: Jurnal Penelitian Pendidikan Biologi Dan Biologi Vol.4 (1)

Tabel 4. Deskripsi jenis lichen (lumut kerak) di Taman Wisata Alam Danau Sicikeh-cikeh

\begin{tabular}{|c|c|c|c|c|}
\hline \multirow{2}{*}{ FAMILI } & \multirow{2}{*}{ SPESIES } & \multicolumn{3}{|c|}{$\begin{array}{c}\text { TIPE TALUS } \\
\end{array}$} \\
\hline & & Crustose & Foliose & Fruticose \\
\hline \multirow{8}{*}{ Parmeliaceae } & Parmotrema arnoldii (Du Rietz) Hale & & $\sqrt{ }$ & \\
\hline & Usnea dasypoga (Acharius.) Nyl. & & & $\sqrt{ }$ \\
\hline & Usnea barbata (L.) Weber ex F.H.Wigg & & & $\sqrt{ }$ \\
\hline & Cetrelia olivetorum (S.) Sticto. & & $\sqrt{ }$ & \\
\hline & Hypogymnia physodes (L.) Nyl. & & $\sqrt{ }$ & \\
\hline & Bulbothrix tabacina (Mont.) Hale & & $\sqrt{ }$ & \\
\hline & Parmelia perlatum (Huds.) M. Choisy & & $\sqrt{ }$ & \\
\hline & Parmelia sulcata (Taylor.) & & & $\sqrt{ }$ \\
\hline \multirow{4}{*}{ Cladoniaceae } & Pseudevernia cladonia (Tuck.) W. L. Culb. & & & $\sqrt{ }$ \\
\hline & Cladonia rangiferina (L.) Weber ex F.H.Wigg & & & $\sqrt{ }$ \\
\hline & Cladonia cristatella (Tuck.) & & & $\sqrt{ }$ \\
\hline & Cladonia squamosa (S.) Hoffm. Var. & & & $\sqrt{ }$ \\
\hline \multirow{3}{*}{ Lobariaceae } & Sticta sylvatica (Hudson). Ach. & & $\sqrt{ }$ & \\
\hline & Pseudocyphellaria anthraspis (Ach.) H. Magn. & & $\sqrt{ }$ & \\
\hline & Sticta crocodia Ach. & & $\sqrt{ }$ & \\
\hline Physciaceae & Heterodermia leucomelos (L.) Kalb & & & $\sqrt{ }$ \\
\hline Pertusariaceae & Ochrolechia subviridis (Hoeg) Erichsen & & & $\sqrt{ }$ \\
\hline Trentepohliaceae & Trentepohlia flava (Kutzing) De Toni & $\sqrt{ }$ & & \\
\hline Pyrenulaceae & Pyrenula cerina Eschw. & $\sqrt{ }$ & & \\
\hline
\end{tabular}

\section{Deskripsi Jenis Lichen}

\section{Parmotrema arnoldii (Du Rietz) Hale}

Mempunyai struktur talus dengan warna hijau keputihan dan bertipe foliose dengan bentuk morfologi tubuh berlekuk. Memiliki rambut halus berwarna hitam di atas talus, Permukaan talus tidak bertepung dan bentuk talus berkerut. Panjang koloninya $7,8 \mathrm{~cm}$. Jenis lichen ini termasuk ke dalam famili Parmeliaceae (Roziaty, 2016b).

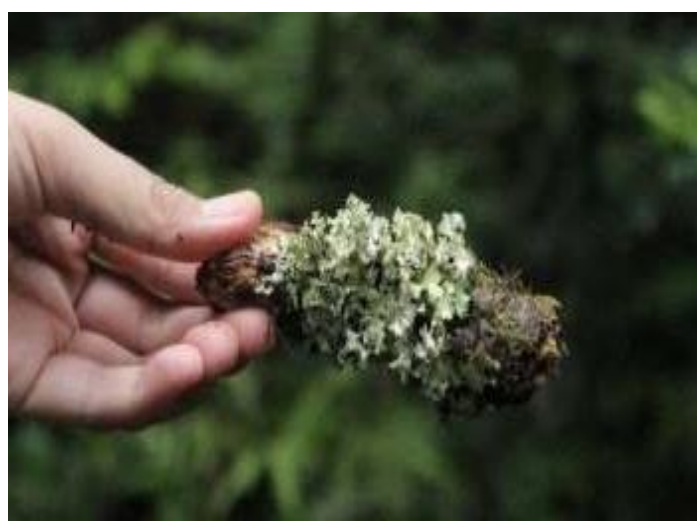

Gambar 1. Parmotrema arnoldii (Du Rietz) Hale

\section{Pseudevernia cladonia (Tuck.) W.L Culb.}

Pseudevernia cladonia (Tuck.) W. L. Club. merupakan jenis lichen yang memiliki talus bertipe fruticose, berwarna hijau muda dengan bentuk morfologi tubuh bertumpuk. Permukaan talus tidak bertepung, bentuk talus halus dan ujung talus bercabang-cabang. Panjang koloninya $7 \mathrm{~cm}$. Jenis lichen ini termasuk ke dalam famili Parmeliaceae.

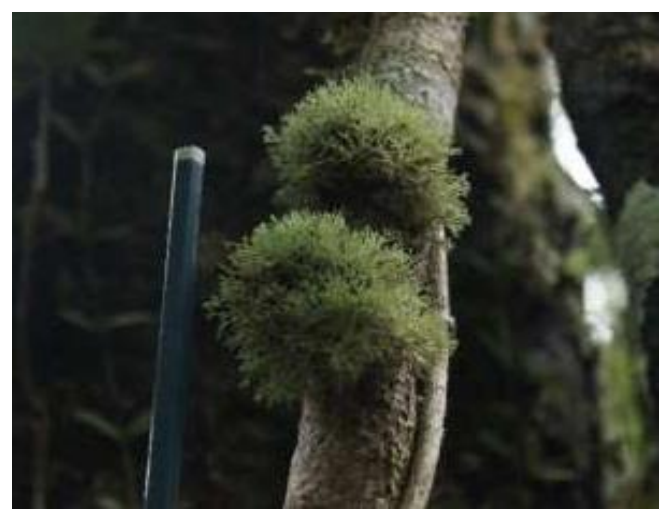

Gambar 2. Pseudevernia cladonia (Tuck.) W.L. Culb.

Sticta sylvatica (Huds) Ach.

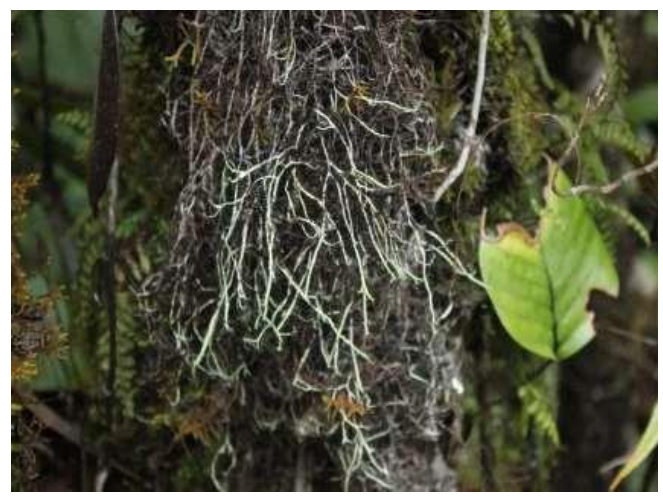

Gambar 3. Sticta sulvatica (Huds) Ach. 
Melfa Aisyah Hutasuhut et al., Identifikasi dan Karakteristik Habitat Jenis Lumut Kerak Di Taman Wisata Alam Sicikeh-Cikeh Kabupaten Dairi Sumatera utara

Jurnal Biolokus: Jurnal Penelitian Pendidikan Biologi Dan Biologi Vol.4 (1)

Sticta sylvatica (Huds) Ach. memiliki talus dengan warna hijau kebiruan dan tipe talus foliose dengan bentuk morfologi tubuh berlekuk. Memiliki rambut halus berwarna hitam di atas talus, bentuk talus kasar dan permukaan talus tidak bertepung. Panjang koloninya $11 \mathrm{~cm}$. Jenis lichen ini termasuk ke dalam famili Lobariaceae.

\section{Cladonia rangiferina (L.) F.H.Wigg}

Cladonia rangiferina (L.) F.H.Wigg merupakan jenis lichen yang memiliki talus dengan tipe fruticose, berwarna hijau dengan bentuk morfologi tubuh bertumpuk. Ujung talus nya bercabang-cabang, bentuk talusnya halus dan permukaan talusnya tidak bertepung. Panjang koloninya $15 \mathrm{~cm}$. Jenis lichen ini termasuk ke dalam famili Cladoniaceae.

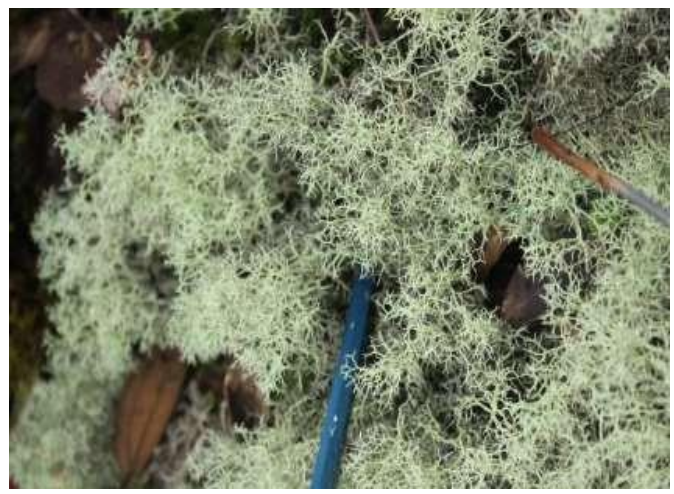

Gambar 4. Cladonia rangiferina (L.) F.H.Wigg.

\section{Cladonia cristatella Tuck.}

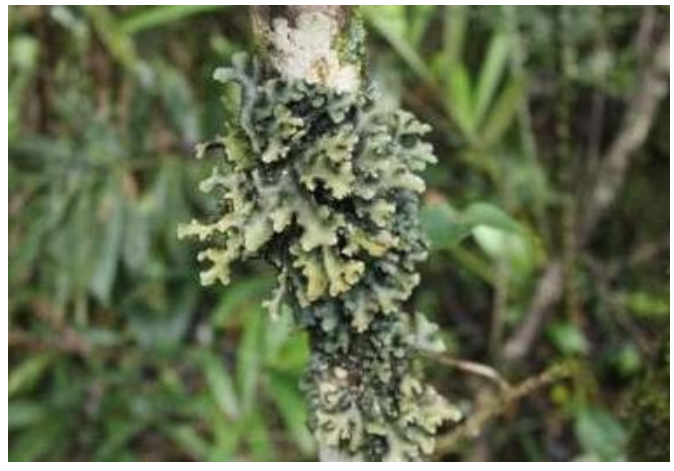

Gambar 5. Cladonia cristatella Tuck.

Cladonia cristatella Tuck. merupakan jenis lichen yang memiliki talus dengan tipe fruticose, berwarna hijau keputihan dengan bentuk morfologi tubuh bertumpuk. Ujung talusnya memiliki pentolan bulat berwarna merah, bentuk talus kasar dan permukaan talus bertepung. Panjang koloninya $15 \mathrm{~cm}$. Jenis lichen ini termasuk ke dalam famili Cladoniaceae.

\section{Heterodermia leucomelos (L.) Kalb}

Heterodermia leucomelos (L.) Kalb merupakan jenis lichen yang memiliki talus dengan tipe fruticose, berwarna hijau dengan bentuk morfologi tubuh bergelombang. Bentuk talus bergaris hitam dan permukaan talus tidak bertepung. Panjang koloninya 17, $5 \mathrm{~cm}$. Jenis lichen ini termasuk ke dalam famili Physciaceae.

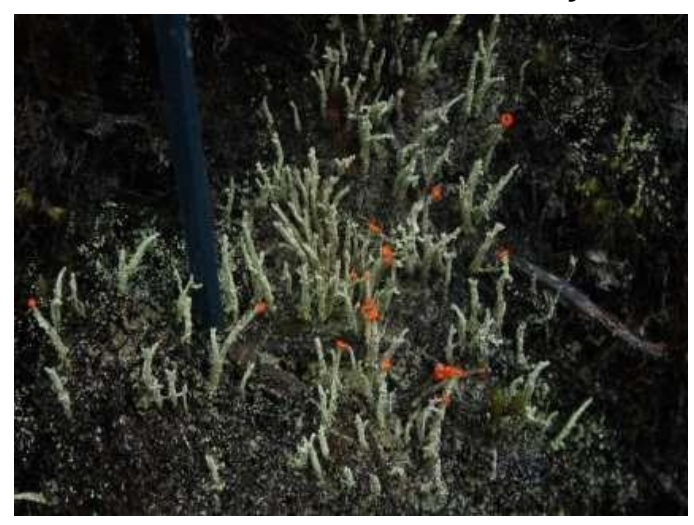

Gambar 6. Heterodermia leucomelos (L.) Kalb.

\section{Ochrolechia subviridis (Hoeg) Erichsen}

Ochrolechia subviridis (Hoeg) Erichsen adalah jenis lichen yang mempunyai warna hijau keabuan dengan tipe talus crustose dengan bentuk morfologi tubuh bertumpuk. Bentuk talus kasar dan permukaan talus bertepung. Panjang koloninya $4,2 \mathrm{~cm}$. Jenis lichen ini termasuk ke dalam famili Pertusariaceae.

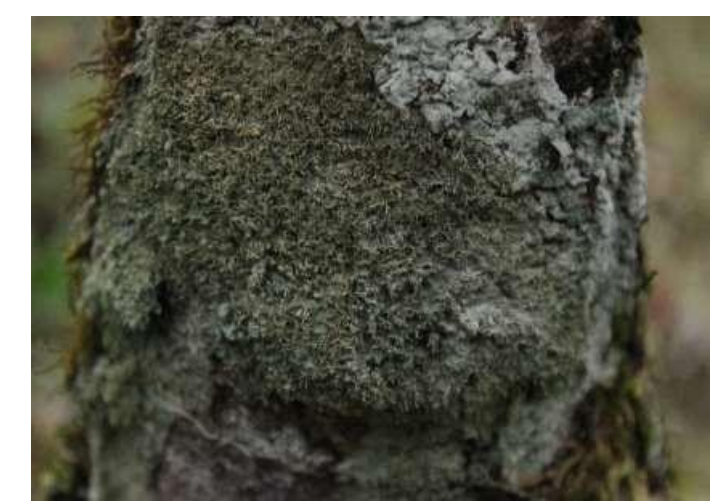

Gambar 7. Ochrolechia subviridis (Hoeg) Erichsen.

\section{Usnea dasypoga (Acharius.) Nyl.}

Usnea dasypoga (Acharius.) Nyl. merupakan jenis lichen yang memiliki talus dengan tipe fruticose seperti semak-semak, berwarna hijau muda dengan bentuk morfologi tubuh 
Melfa Aisyah Hutasuhut et al., Identifikasi dan Karakteristik Habitat Jenis Lumut Kerak Di Taman Wisata Alam Sicikeh-Cikeh Kabupaten Dairi Sumatera utara

Jurnal Biolokus: Jurnal Penelitian Pendidikan Biologi Dan Biologi Vol.4 (1)

bergelombang dan berbentuk seperti rambut dan tali. Seluruh bagian talus bercabang-cabang, bentuk talus seperti tepung dan permukaan talus tidak bertepung. Panjang koloninya $9 \mathrm{~cm}$. Jenis lichen ini termasuk ke dalam famili Parmeliacea.

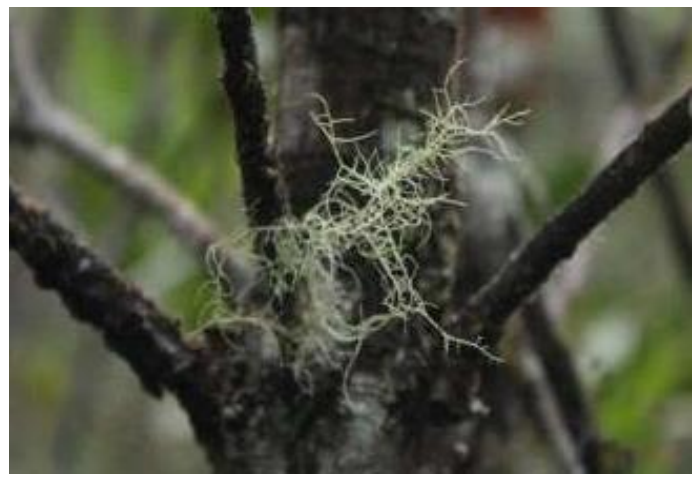

Gambar 8. Usnea dasypoga (Acharius.) Nyl.

\section{Trentepohlia flava (Kutzing) De Toni}

Trentepohlia flava (Kutzing) De Toni merupakan jenis lichen yang memiliki talus dengan tipe crustose, berwarna jingga dengan bentuk morfologi tubuh bergelombang. Bentuk talus kasar dan permukaan talus bertepung. Panjang koloninya $15 \mathrm{~cm}$. Jenis lichen ini termasuk ke dalam famili Trentepohliaceae.

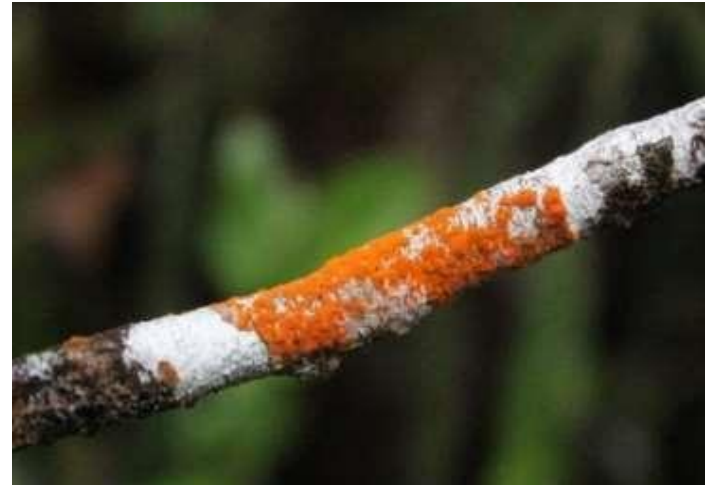

Gambar 9. Trentepohlia flava (Kutzing) De Toni

\section{Pseudocyphellaria anthraspis (Ach.) H. Magn.}

Pseudocyphellaria antharaspis (Ach.) H. Magn adalah jenis lichen warna hijau coklat dan tipe talus foliose dengan bentuk morfologi tubuh berlekuk. Bentuk talus bergaris hitam dan permukaan talus tidak bertepung. Panjang koloninya $14,5 \mathrm{~cm}$. Jenis lichen ini termasuk ke dalam famili Lobariaceae.

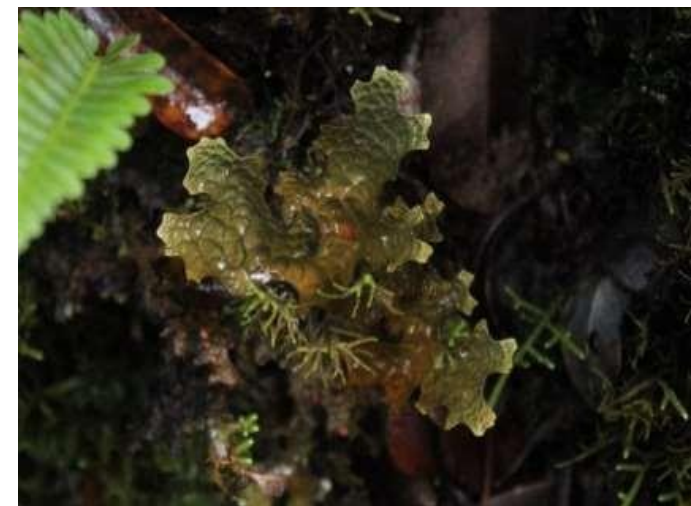

Gambar 10. Pseudocyphellaria antharaspis (Ach.) H. Magn.

\section{Usnea barbata (L.) Weber ex F.H.Wigg}

Usnea barbata (L.) Weber ex F.H. Wigg merupakan jenis lichen yang memiliki talus dengan tipe fruticose, berwarna hijau muda dengan bentuk morfologi tubuh bergelombang. Seluruh bagian talus bercabang-cabang, bentuk talus halus dan permukaan talus bertepung. Panjang koloninya $42 \mathrm{~cm}$. Jenis lichen ini termasuk ke dalam famili Parmeliacea.

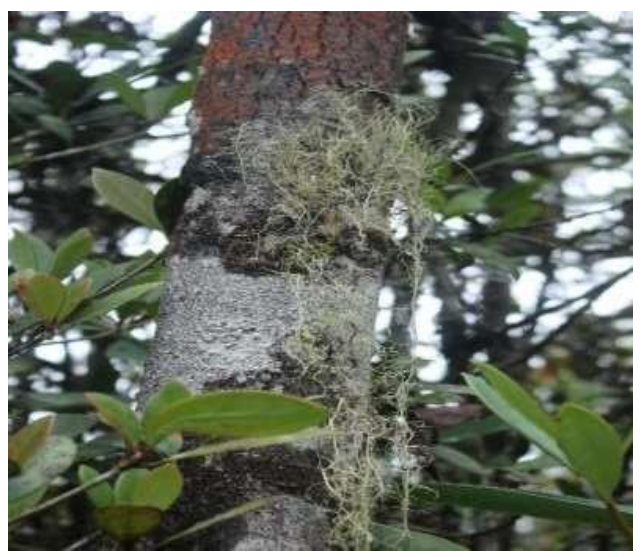

Gambar 11. Usnea barbata (L.) Weber ex F.H. Wigg

Cladonia squamosa (S.) Hoffm. Var.

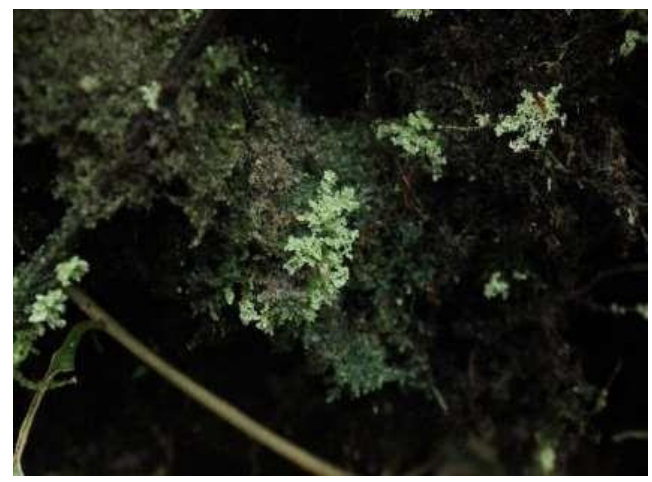

Gambar 12. Cladonia squamosa (S.) Hoffm. Var 
Melfa Aisyah Hutasuhut et al., Identifikasi dan Karakteristik Habitat Jenis Lumut Kerak Di Taman Wisata Alam Sicikeh-Cikeh Kabupaten Dairi Sumatera utara

Jurnal Biolokus: Jurnal Penelitian Pendidikan Biologi Dan Biologi Vol.4 (1)

Cladonia squamosa (S.) Hoffm. Var. merupakan jenis lichen yang memiliki talus dengan tipe fruticose, berwarna hijau dengan bentuk morfologi tubuh bertumpuk. Bentuk halus dan permukaan talus bertepung. Panjang koloninya $9 \mathrm{~cm}$. Jenis lichen ini termasuk ke dalam famili Cladoniaceae.

\section{Cetrelia olivetorum (S.) Stricto.}

Cetrelia olivetorum (S.) Stricto adalah jenis lichen yang mempunyai warna hijau kekuningan dan talus dengan tipe foliose dengan bentuk morfologi tubuh berlekuk. Bentuk talus berkerut dan permukaan talus tidak bertepung. Panjang koloninya $14,5 \mathrm{~cm}$. Jenis lichen ini termasuk ke dalam famili Parmeliacea.

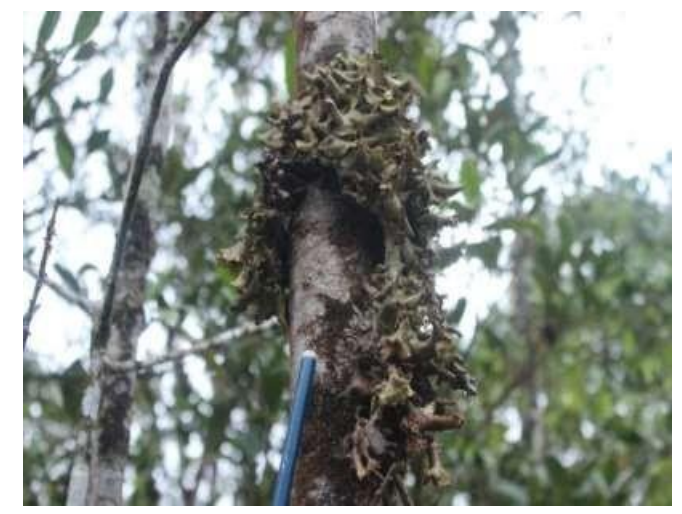

Gambar 13. Cetrelia olivetorum (S.) Stricto.

\section{Hypogymnia physodes (L.) Nyl.}

Hypogymnia physodes (L.) Nyl. adalah jenis lichen dengan warna hijau dan talus dengan tipe foliose, dengan bentuk morfologi tubuh berlekuk. Bentuk talus berkerut dan permukaan talus tidak bertepung. Panjang koloninya $3,5 \mathrm{~cm}$. Jenis lichen ini termasuk ke dalam famili Parmeliaceae.

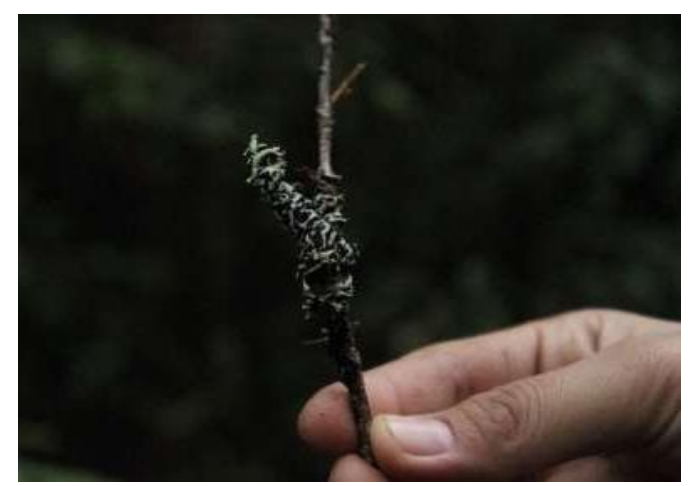

Gambar 14. Hypogymnia physodes (L.) Nyl.

\section{Bulbothrix tabacina (Mont.) Hale}

Bulbothrix tabacina (Mont.) Hale adalah jenis lichen yang mempunyai warna hijau, talus dengan tipe foliose dengan bentuk morfologi tubuh bertumpuk. Bentuk talus halus dan permukaan talus bertepung. Panjang koloninya $9 \mathrm{~cm}$. Jenis lichen ini termasuk ke dalam famili Parmeliaceae.

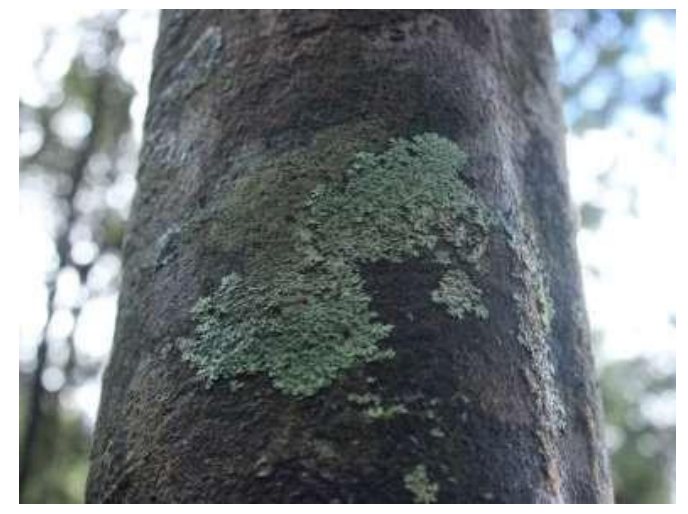

Gambar 15. Bulbothrix tabacina (Mont.) Hale.

\section{Parmotrema perlatum (Huds.) M. Choisy}

Parmotrema perlatum (Huds.) M. Choisy adalah lichen yang mempunyai warna hijau muda, tipe talus foliose dengan bentuk morfologi tubuh bergelombang. Bentuk talus halus dan permukaan talus tidak bertepung. Panjang koloninya $13 \mathrm{~cm}$. Jenis lichen ini termasuk ke dalam famili Parmeliaceae.

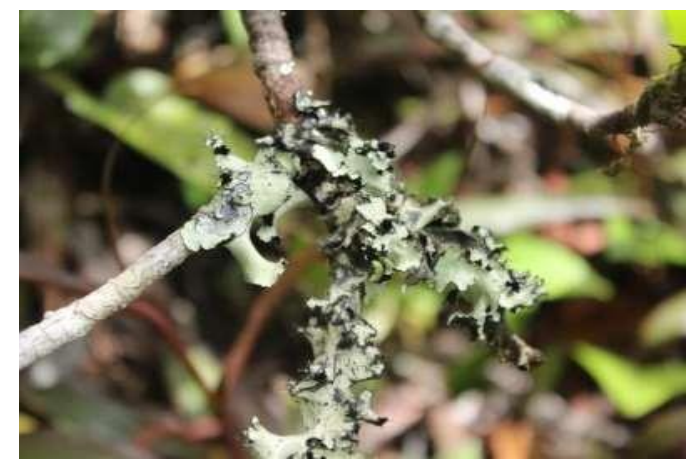

Gambar 16. Parmotrema perlatum (Huds.) M. Choisy.

\section{Parmelia sulcata Taylor.}

Parmelia sulcata Taylor. adalah lichen yang mempunyai warna hijau bintik hitam, talus dengan tipe foliose dengan bentuk morfologi tubuh bergelombang. Bentuk talus seperti tepung dan permukaan talus bertepung. Panjang koloninya $5 \mathrm{~cm}$. Jenis lichen ini termasuk ke dalam famili Parmeliaceae. 
Melfa Aisyah Hutasuhut et al., Identifikasi dan Karakteristik Habitat Jenis Lumut Kerak

Di Taman Wisata Alam Sicikeh-Cikeh Kabupaten Dairi Sumatera utara

Jurnal Biolokus: Jurnal Penelitian Pendidikan Biologi Dan Biologi Vol.4 (1)

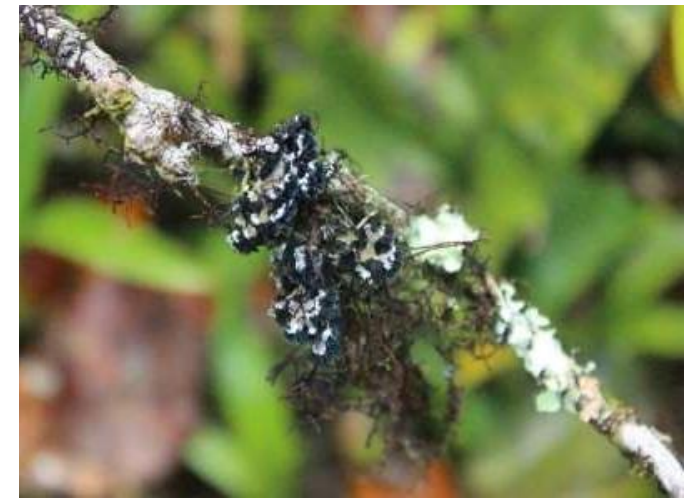

Gambar 17. Parmelia sulcata Taylor.

\section{Pyrenula cerina Eschw.}

Pyrenula cerina Eschw. merupakan jenis lichen yang memiliki talus dengan tipe crustose, berwarna kuning kecoklatan dengan bentuk morfologi tubuh berlekuk. Bentuk talus halus dan permukaan talus tidak bertepung. Panjang koloninya $5 \mathrm{~cm}$. Jenis lichen ini termasuk ke dalam famili Pyrenulaceae.

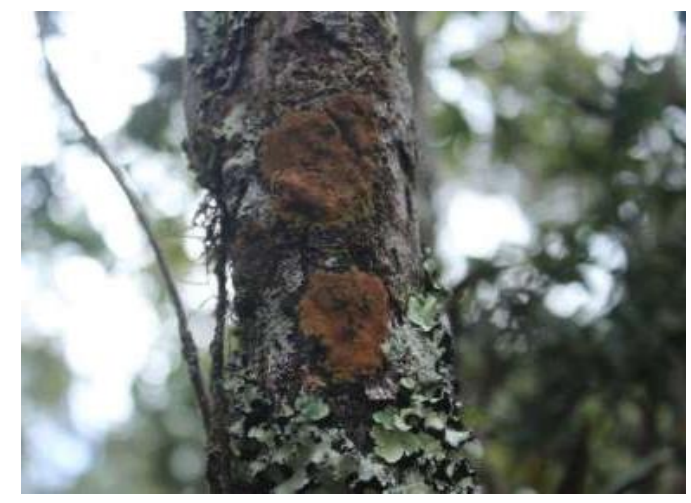

Gambar 18. Pyrenula cerina Eschw.

\section{Sticta crocodia Ach.}

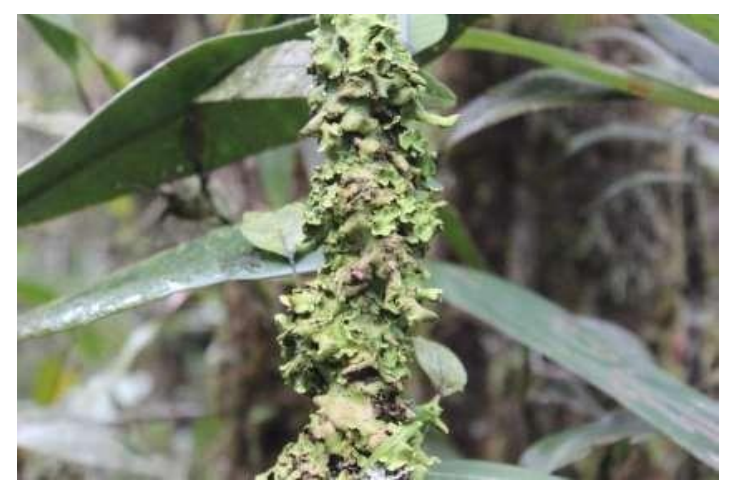

Gambar 19. Sticta crocodia Ach.

Sticta crocodia Ach. adalah lichen dengan warna hijau, tipe talus foliose dengan bentuk morfologi tubuh bergelombang. Bentuk talus tebal dan permukaan talus tidak bertepung.
Panjang koloninya $9 \mathrm{~cm}$. Jenis lichen ini termasuk ke dalam famili Lobariaceae.

Suhu udara di wilayah penelitian berkisar $20^{\circ} \mathrm{C}-24^{\circ} \mathrm{C}$ dan kelembaban udara berkisar dari $80-88 \%$, suhu tanah berkisar dari $18^{\circ} \mathrm{C}-21^{\circ} \mathrm{C}$, kelembaban tanah berkisar dari 70-80\%, pH tanah berkisar dari 5-7 dan intesitas cahaya pada saat penelitian 1124-1126 cd. Suhu lingkungan diatas $45^{\circ} \mathrm{C}$ mampu merusak klorofil lichen sehingga dibutuhkan suhu dibawah $40^{\circ} \mathrm{C}$ untuk pertumbuhan maksimal lichen dan intensitas cahaya sebesar $1025 \mathrm{~cd}$ adalah intensitas terendah lichen agar dapat melakukan fotosintesis dengan baik (Fithri, 2017).

$$
\text { Berdasarkan kondisi lingkungan }
$$

penelitian, Lichen mampu hidup di TWA Danau Sicikeh-cikeh karena adanya dukungan dari faktor fisik lingkungan yang dapat mempengaruhi keberadaan dan penyebaran lichen di lingkungan penelitian.

\section{PENUTUP}

Berdasarkan hasil penelitian yang diperoleh tentang inventarisasi lichen (lumut kerak) di Taman Wisata Alam Danau Sicikehcikeh Desa Lae Hole Kecamatan Parbuluan Kabupaten Dairi Sumatera Utara terdapat 19 spesies dari 7 famili lichen. Spesies dari famili Parmeliaceae merupakan spesies yang paling banyak ditemukan sebanyak 8 spesies dengan ciri morfologi seperti lembaran daun, warnanya hijau hingga hijau keabuabuan.

Karakteristik habitat lichen yang diperoleh dari penelitian ini yaitu dapat menempel pada substrat serasah sebanyak 1 spesies, menempel pada substrat tanah sebanyak 2 spesies dan ditemukan epifit di pohon sebanyak 16 spesies.

\section{REFERENSI}

Asih, S. M., Jumari, Murningsih. (2013). Keanekaragaman jenis lichen epifit pada hutan kopi dan hutan campuran di Nglimut Gonoharjo Kendal. Jurnal Biologi, 2(2), 27-36. Chandra, H.R. (2015). Akumulasi timbal (Pb) dan keanekaragaman jenis lichenes di Taman Kota Medan. Jurnal Biologi Lingkungan, Industri, Kesehatan, 2(1), 23-36. 
Jurnal Biolokus: Jurnal Penelitian Pendidikan Biologi Dan Biologi Vol.4 (1)

Fithri, S. (2017). Keanekaragaman lichen di Brayeun Kecamatan Leupung Aceh Besar sebagai referensi mata kuliah mikologi [Skripsi]. UIN Ar-Raniry Banda Aceh.

Hasairin, A. (2016). Kajian lichen di Kota Medan dan Deli Serdang sebagai bioindikator kualitas udara [Disertasi]. Universitas Sumatera Utara.

Laksono, A. (2016). Identifikasi jenis lichen sebagai bioindikator kualitas udara di kampus Institut Agama Islam Negeri Raden Intan Lampung [Skripsi]. IAIN Raden Intan Lampung.

Marianingsih, P., Evi, A., Niska, N. (2017). Keanekaragaman liken Pulau Tunda Banten sebagai konten pembelajaran keanekagaman hayati berbasis potensi lokal. Makalah dipresentasikan pada Seminar Nasional Pendidikan Universitas Sultan Ageng Tirtayasa, Serang Banten.

Mulyadi. (2007). Jenis lichen di Kawasan Gugop Pulo Kecamatan Pulo Aceh Kabupaten Aceh Besar. Jurnal Biotik, 5(2), 83-87.

Murningsih, H.M. (2016). Jenis-jenis Lichen di Kampus Undip Semarang. Jurnal Bioma, 18(1), 20-29.

Muslim \& Hasairin, A. (2018). Eksplorasi lichen pada tegakan pohon di area taman margasatwa (medan zoo) Simalingkar Medan Sumatera Utara. Jurnal Biosains, 4(3), 145-153.

Mulyani, N. (2021). Karakteristik lichen di kawasan Air Terjun Tingkat Tujuh Desa Batu Itam Kecamatan Tapaktuan Aceh Selatan sebagai referensi mata kuliah botani tumbuhan rendah [Skripsi]. UIN AR-Raniry Banda Aceh.

Roziaty, E. (2016a). Identifikasi lumut kerak (lichen) di area kampus Universitas Muhammadiyah Surakarta. Proceeding Biology Education Conference, 13(1) 770776.

Roziaty, E. (2016b) Kajian lichen: Morfologi, habitat dan bioindikator kualitas udara ambien akibat polusi kendaraan bermotor. Bioeksperimen, 2(1), 54-66.

Septiana, E. (2011). Potensi lichen sebagai sumber bahan obat: Suatu kajian pustaka. Jurnal Biologi, 15(1), 1-5.

Tjitrosoepomo, G. (2005). Taksonomi tumbuhan (schizophyta, thallophyta, bryophyta, pteridophyta). Gadjah Mada University Press.
Utari, R.T. \& Roziaty, E. (2017). Karakteristik morfologi lichen crustose di kawasan Hutan Sekipan Desa Kalisoro Tawangmangu Karanganyar Provinsi Jawa Tengah [Skripsi]. Universitas Muhammadiyah Surakarta.

Wanggai, F. (2009). Manajemen hutan. Grasindo. 